\title{
A POSSIBLE RELATIONSHIP BETWEEN SERUM HOMOCYSTEINE LEVEL AND IgA NEPHROPATHY IN CHILDREN
}

\author{
ÇOCUKLARDA SERUM HOMOSISTEIN DÜZEYI ILE IgA NEFROPATISI ARASINDAKI \\ OLASI ILIŞKI
}

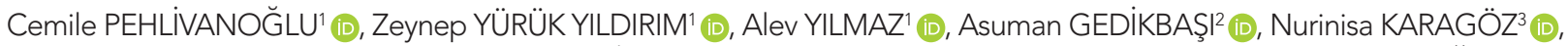

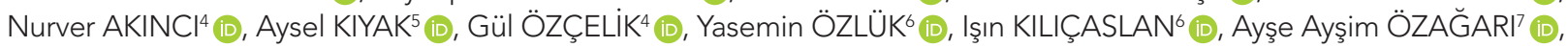
Bağdagül YAVAŞ AKSU² (D), Sevinç EMRE' (1)
\end{abstract}

\begin{abstract}
${ }^{1}$ Istanbul University, Istanbul Faculty of Medicine, Department of Pediatric Nephrology, Istanbul, Turkey
${ }^{2}$ Istanbul University, Institute of Child Health, Department of Pediatric Basic Sciences, Istanbul, Turkey

${ }^{3}$ Istanbul University, Istanbul Faculty of Medicine, Department of Child Health and Diseases, Istanbul, Turkey

${ }^{4}$ Şişli Hamidiye Etfal Training and Research Hospital, Department of Pediatric Nephrology, Istanbul, Turkey

${ }^{5}$ Kanuni Sultan Süleyman Research and Training Hospital, Department of Pediatric Nephrology, Istanbul, Turkey

${ }^{6}$ Istanbul University, Istanbul Faculty of Medicine, Department of Pathology, Istanbul, Turkey

${ }^{7}$ Şişli Hamidiye Etfal Training and Research Hospital, Department of Pathology, Istanbul, Turkey
\end{abstract}

ORCID IDs of the authors: C.P. 0000-0002-6949-8922; Z.Y.Y. 0000-0003-2891-2231; A.Y. 0000-0003-1743-1491; A.G. 0000-0001-7121-6077; N.K. 0000-0002-4575-4100; N.A. 0000-0002-8355-4214; A.K. 0000-0003-1073-000X; G.Ö. 0000-0001-9394-2977; Y.Ö. 0000-0002-7191-0488; I.K. 0000-0002-4206-9941; A.A.Ö. 0000-0003-2343-1236; B.Y.A. 0000-0003-3274-8024; S.E. 0000-0002-9708-9480

Cite this article as: Pehlivanoglu C, Yuruk Yildirim Z, Yilmaz A, Gedikbasi A, Karagoz N, Akinci N, et al. A possible relationship between serum homocysteine level and IgA nephropathy in children. J Ist Faculty Med 2021;84(4):568-73. doi: 10.26650/IUITFD.2021.847530

\section{ABSTRACT}

Objective: The evidences from experimental and epidemiological studies suggests that elevated serum homocysteine levels may lead to renal injury and may be a significant risk factor for the development of chronic kidney disease. The aim of this study was to investigate a possible relationship between serum homocysteine level and crescent formation in children with IgA nephropathy and Henoch-Schonlein purpura nephritis.

Material and Methods: A total of 31 patients diagnosed as biopsy proven IgA nephropathy and Henoch-Schonlein purpura nephritis and idiopathic crescentic glomerulonephritis in three Pediatric Nephrology centers within the last five years and 25 healthy controls were enrolled in the study.

Results: Homocysteine levels of patients were higher than the upper limit of normal value and also higher than the controls $(p=0.0001)$. There was no significant difference between the patients with or without crescent formation regarding homocysteine levels $(p>0.05)$. Presence or severity of proteinuria was not related to homocysteine levels ( $p>0.05)$.

Conclusion: Serum homocysteine levels are elevated in patients with IgA nephropathy and Henoch-Schonlein purpura nephritis.

\section{ÖZET}

Amaç: Deneysel ve epidemiyolojik çalışmalar, yüksek serum homosistein düzeylerinin renal hasara yol açabileceğini ve kronik böbrek hastalığı gelişimi için önemli bir risk faktörü olabileceğini göstermektedir. Çalışmamızın amacı IgA nefropatisi ve HenochSchönlein purpura nefriti olan hastalarda serum homosistein düzeyleri ile kresent oluşumu arasında bir ilişki olup olmadığını belirlemektir.

Gereç ve Yöntemler: Üç pediatrik nefroloji merkezinde son beş yılda biyopsi ile IgA nefropatisi, Henoch-Schönlein purpura nefriti ve idiopatik kresentik glomerulonefrit tanısı alan 31 hasta ve 25 sağlıklı kontrol çalışmaya alındı.

Bulgular: Hastaların homosistein düzeyleri normal değerin üst sınırından ve kontrollerden de daha yüksekti $(p=0,0001)$. Biyopside kresent görülen ve görülmeyen hastalar arasında da homosistein düzeyleri açısından anlamlı fark yoktu $(p>0,05)$. Proteinüri varlığı ve şiddeti ile homosistein düzeyleri arasında ilişki saptanmadi $(p>0,05)$

Sonuç: Serum homosistein düzeyleri lgA nefropatisi ve HenochSchonlein purpura nefriti olan hastalarda yüksek bulunmuştur. Sonuçlarımız, bu hasta grubunda yüksek serum homosistein

Corresponding author/iletişim kurulacak yazar: dr.cemilep@yandex.com

Submitted/Başvuru: 29.12.2020 • Revision Requested/Revizyon Talebi: 07.05.2021 •

Last Revision Received/Son Revizyon: 05.07.2021 • Accepted/Kabul: 06.07.2021 • Published Online/Online Yayın: 29.09.2021 
Our results suggest that elevated serum homocysteine levels may be related to segmental glomerulosclerosis in these patient groups.

Keywords: IgA nephropathy, homocysteine, crescent düzeylerinin segmental glomerüloskleroz ile ilişkili olabileceğini düşündürmektedir.

Anahtar Kelimeler: IgA nefropatisi, homosistein, kresent

\section{INTRODUCTION}

$\lg A$ nephropathy (IgAN), one of the most common glomerulonephritis in adults and children, may progress to end-stage renal disease (ESRD) in $20-50 \%$ of patients within 20 years (1-3). Although IgAN usually has a slow progression course, acute deterioration in renal function due to crescent formation may occur during the course of the disease $(3,4)$. It has been reported that crescent formation in IgAN may influence renal outcomes and aggressive immunosuppressive treatment may be required if the number of crescents involves $>50 \%$ of the glomeruli in a renal biopsy (5). The Kidney Disease Improving Global Outcomes (KDIGO) guidelines recommend that HenochSchonlein Purpura Nephritis (HSPN) should be treated the same as IgAN because it has the same histopathologic features as IgAN in kidney biopsies (5). Crescent formation in glomeruli begins with the emergence of ruptures of glomerular capillary walls (6). These ruptures permit coagulation factors and cells including monocytes and lymphocytes to enter the Bowman's space, which results in crescent formation (6). There is some evidence to suggest that elevated concentration of serum homocysteine (Hcy) leads to endothelial cell injury, which results in stimulation of the coagulation system and resistance of anticoagulation activity on the endothelial surface $(7,8)$. Moreover, it has been reported that hyperhomocysteinemia causes glomerular and tubulointerstitial damage in several ways, such as increasing oxidative stress, stimulating monocyte chemoattractant protein-1 (MCP-1) expression, and nuclear factor kappa B activation (NF-B) (9-14).

We observed hyperhomocysteinemia in two patients with IgAN and crescent formation in their renal biopsy. Using observations from these two patients, we hypothesized that crescent formation may be related to hyperhomocysteinemia in IgAN. The aim of the study was to investigate whether a relationship exists between serum Hcy level and crescent formation in children with IgAN and HSPN.

\section{MATERIALS AND METHODS}

Thirty-one patients with renal biopsy-proven IgAN $(n=17), H S P N(n=12)$, and idiopathic crescentic glomerulonephritis (ICGN; $n=2$ ) in three pediatric nephrology centers were enrolled in the study. The control group was consisted of 25 age matched healthy children without medical history of any chronic disease or renal disorder.
This study was approved by the Ethical Committee of Istanbul University Istanbul Faculty of Medicine (Date: 27.05.2013, No: 640). Informed consent was obtained from the parents of all participants. A physical examination was performed, and the patients' medical history and clinical findings were recorded at the time of the sampling.

Baseline investigations including serum urea, creatinine, electrolytes, lipids, total protein, albumin, Hcy, urinalysis and 24-hour urinary protein were performed in the patient group. Moreover, serum levels of vitamin B12 and folic acid, thyroid function tests, methylenetetrahydrofolate reductase (MTHFR) 677 and MTHFR 1298 genetic mutation analysis were also performed because hyperhomocysteinemia may be caused by deficiency of folic acid and vitamin B12, hypothyroidism or decreased enzyme activity of MTHFR due to genetic mutations. A physical examination was performed and serum urea, creatinine, Hcy, B12 and urinalysis were performed in the control group.

IgAN, HSPN, and ICGN were diagnosed based on clinical, laboratory and immunehistopathologic findings. Mesangial hypercellularity with predominant IgA deposition in the mesangium and/or capillary wall was described as IgAN in patients without systemic involvement. The MEST score was evaluated as mesangial hypercellularity $(\mathrm{MO}, \mathrm{M} 1)$, endocapillary hypercellularity (E0, E1), segmental glomerulosclerosis (S0, S1) and tubular atrophy/ interstitial fibrosis (TO, T1), in accordance with the Oxford classification (4). Presence or absence of crescents was recorded. Henoch-Schonlein Purpura was diagnosed using the EULAR/PReS consensus criteria (15). Extracapillary proliferation of cells in the Bowman's space with more than two cell layers was described as cellular crescent (16). Idiopathic crescents in more than $50 \%$ of glomeruli on renal biopsies were described as ICGN.

Hypertension was defined as average clinic measured systolic and/or diastolic blood pressure $\geq 95^{\text {th }}$ percentile on the basis of age, sex and height percentiles (17).

The mean estimated glomerular filtration rate (eGFR) was calculated according to the Schwartz formula (18). Hematuria was defined as five or more red blood cells per high power field in a urine specimen (19). Proteinuria was determined as a positive dipstick reading of $\geq 1+$, urinary excretion $\geq 4 \mathrm{mg} /$ $\mathrm{m}^{2} /$ per hour in urine over a period of 24 hours (19). 
Venous blood samples were collected in tubes from the antecubital vein, followed by overnight fasting. The tubes were centrifuged at 2000 relative centrifugal force (RCF) (10 minutes) to remove the serum. The blood and serum samples were analyzed within an hour. Serum glucose, urea, creatinine, total cholesterol, HDL cholesterol, triglyceride, total protein, albumin, thyrotropin (TSH), free triiodothyronine (T3), free thyroxine (T4), and other biochemical parameters were determined using a Beckman Coulter AU5800 Clinical Chemistry, Dxl 800 Immunoassay Auto-Analyzer and commercial kits (Beckman Coulter, CA, USA). Urine protein levels were measured using Siemens BNII nephelometric system (Siemens Healthcare Diagnostics, USA) using reagents and protocols provided by the manufacturer. Serum Hcy, vitamin B12, and folic acid were determined using an Immulite 2000 chemiluminescence auto-analyzer and commercial kits (Siemens, USA). Hyperhomocysteinemia was defined as serum levels of Hcy $>12 \mu \mathrm{g} / \mathrm{L}$ (20). Deficiency of vitamin B12 was defined as $<200 \mathrm{pg} / \mathrm{mL}$ and deficiency of folic acid was defined as $<3 \mathrm{ng} / \mathrm{mL}(21,22)$.

Genomic deoxyribonucleic acid (DNA), was isolated from peripheral blood leukocytes using the High Pure PCR Template Preparation Kit (Roche Diagnostics GmbH, Mannheim, Germany) for C677T and A1298C of MTHFR gene mutations. Detection of gene mutations was achieved using rapid capillary PCR with melting curve analysis using fluorescence-labeled hybridization probes in a Light Cycler (Roche Diagnostics GmbH, Mannheim, Germany).

Statistical analysis in this study was performed with the package program Number Cruncher Statistical System (NCSS) 2007 Statistical Software (Utah, USA). Patients mentioned in the background section were excluded from statistical analyses because of their low eGFR to provide group homogeneity. In addition to standard descriptive statistical calculations (mean, standard deviation, median and (QR), the Kruskal-Wallis test was used in the comparison of groups, the Mann-Whitney $U$ test was used in the comparison of two groups, and the Chisquare test was performed to evaluate qualitative data. Statistical significance level was established at $p<0.05$.

\section{RESULTS}

The median age of the patients and controls were 11.6 years (range: $3.53-19.37$ years) and 12.60 years (range: 9.53-14.84), respectively. There was no significant difference between patient and control groups regarding age and gender distribution $(p=0.145$ and $p=0.186$; respectively). The median follow-up duration of the patients was 61.5 months (range: 3-365 months). The patient's characteristics are given in Table 1.

Mean serum Hcy level was significantly higher in the patients than in the controls ( $p=0.0001$ ) (Table 2, Figure 1). Hcy levels
Table 1: Characteristics of the study group

\begin{tabular}{lc}
\hline Patients characteristics & $\mathbf{n}(\%)$ \\
\hline Total & $31(100)$ \\
Histopathologic diagnosis & \\
IgA nephropathy & $17(54.8)$ \\
Henoch-Schonlein nephritis & $12(38.7)$ \\
Idiopathic crescentic glomerulonephritis & $2(6.5)$ \\
Presence of crescent & $11(35.5)$ \\
IgA nephropathy & $3(27.3)$ \\
Henoch-Schonlein nephritis & $6(54.5)$ \\
Idiopathic crescentic & $2(18.2)$ \\
Glomerulonephritis & \\
Presenting symptoms & \\
Macroscopic hematuria & $12(38.7)$ \\
Hypertension & $6(19.3)$ \\
Rash & $12(38.7)$ \\
Arthritis/arthralgia & $9(29)$ \\
Proteinuria & $17(54.8)$ \\
Nephrotic proteinuria & $3(9.6)$ \\
Deterioration of kidney function & $4(12.9)$ \\
Actual situation of the patients & \\
Microscopic hematuria & $9(29)$ \\
Non-nephrotic proteinuria & $18(58)$ \\
Hypoalbuminemia & $0(0)$ \\
Hypertension & $2(6.4)$ \\
Hyperlipidemia & $7(22.5)$ \\
Deterioration of kidney functions & $1(3.2)$ \\
\hline
\end{tabular}

were not significantly different in the patients with IgAN and HSPN (Table 2). The presence or severity of proteinuria were not related to Hcy levels ( $p>0.05$ ) (Table 2).

Eleven (35.5\%) of the patients had crescent formation in renal biopsy. Crescents existed in $\geq 50 \%$ of glomeruli in two patients with ICGN, in one patient with IgAN, and in one patient with HSPN. Other patients with IgAN and HSPN had crescents in $\leq 25 \%$ of glomeruli. There was no significant difference between the patients with and without crescent formation regarding Hcy levels $(p=0.17)$ (Table 2).

According to the MEST score, $40.7 \%$ of the patients were assessed as $\mathrm{M} 1,48.1 \%$ as $\mathrm{E} 1,22.2 \%$ as $\mathrm{S} 1$, and $7.4 \%$ as $\mathrm{T} 1$. Serum Hcy level was significantly higher in patients who were assessed as $\mathrm{S} 1(29.36 \pm 11.99 \mu \mathrm{g} / \mathrm{L})$ than in those assessed as SO $(19.74 \pm 4.15 \mu \mathrm{g} / \mathrm{L})$ with regard to MEST score $(p=0.009)$ although other parameters of the score were not related to Hcy level $(p>0.05)$.

As an interesting observation, Hcy levels were higher than the upper limit of normal values in all our patients (Figure 1). Mean vitamin B12 level was significantly lower in the patient group than in the controls $(238.77 \pm 127.24$ vs $378.88 \pm 69.63 ; p=0.0001$ )(Table 2). Vitamin B12 level was lower than $200 \mathrm{ng} / \mathrm{mL}$ in 12 patients (38.7\%) in our 
Table 2: Serum homocysteine, folic acid, and vitamin B12 levels in controls and patients according to histopathology and proteinuria

\begin{tabular}{|c|c|c|c|}
\hline & $\begin{array}{c}\text { Homocysteine } \\
\text { mean } \pm S D(\mu \mathrm{g} / \mathrm{L})\end{array}$ & $\begin{array}{c}\text { Vitamin B12 } \\
\text { mean } \pm S D(p g / m L)\end{array}$ & $\begin{array}{c}\text { Folic acid } \\
\text { mean } \pm S D(\mathrm{ng} / \mathrm{mL})\end{array}$ \\
\hline $\begin{array}{l}\text { Patients }(n=29) \\
\text { Controls }(n=25) \\
p\end{array}$ & $\begin{array}{c}23.18 \pm 8.66 \\
8.88 \pm 1.79 \\
0.0001\end{array}$ & $\begin{array}{c}238.77 \pm 127.24 \\
378.88 \pm 69.63 \\
0.0001\end{array}$ & $\begin{array}{c}7.52 \pm 2.78 \\
8,01 \pm 1.46 \\
0.427\end{array}$ \\
\hline 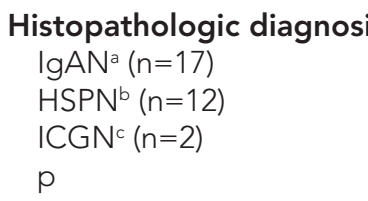 & $\begin{array}{c}22.67 \pm 8.49 \\
21.34 \pm 5.44 \\
38.65 \pm 15.76 \\
0.790\end{array}$ & $\begin{array}{c}222 \pm 69.88 \\
249.33 \pm 191.52 \\
318 \pm 41.01 \\
0.413\end{array}$ & $\begin{array}{l}8.87 \pm 3.74 \\
7.52 \pm 2.78 \\
9.05 \pm 0.40 \\
0.376\end{array}$ \\
\hline $\begin{array}{l}\text { Presence of crescent } \\
\text { Crescent }(+)(n=11) \\
\text { Crescent }(-)(n=20) \\
p\end{array}$ & $\begin{array}{c}26.71 \pm 12.16 \\
21.25 \pm 5.43 \\
0.173\end{array}$ & $\begin{array}{c}261 \pm 168.08 \\
226.55 \pm 105.38 \\
0.695\end{array}$ & $\begin{array}{c}7.69 \pm 2.39 \\
8.73 \pm 3.69 \\
0.536\end{array}$ \\
\hline $\begin{array}{l}\text { Presence of proteinuria } \\
\text { Proteinuria }(+)(n=18) \\
\text { Proteinuria }(-)(n=13) \\
\text { p }\end{array}$ & $\begin{array}{c}22.56 \pm 8.41 \\
24.06 \pm 9.28 \\
0.575\end{array}$ & $\begin{array}{c}218.56 \pm 102.02 \\
266.77 \pm 160.07 \\
0.378\end{array}$ & $\begin{array}{c}8.24 \pm 4.03 \\
8.52 \pm 1.98 \\
0.328\end{array}$ \\
\hline $\begin{array}{l}\text { Severity of proteinuria } \\
<150 \mathrm{mg} / 24 \mathrm{~h}(\mathrm{n}=13) \\
150-500 \mathrm{mg} / 24 \mathrm{~h}(\mathrm{n}=10) \\
500-1000 \mathrm{mg} / 24 \mathrm{~h}(\mathrm{n}=8) \\
\mathrm{p}\end{array}$ & $\begin{array}{c}24.06 \pm 9.28 \\
20.26 \pm 3.59 \\
25.44 \pm 11.75 \\
0.480\end{array}$ & $\begin{array}{c}266.77 \pm 160.07 \\
198.5 \pm 41.26 \\
243.63 \pm 147.64 \\
0.625\end{array}$ & $\begin{array}{c}8.52 \pm 1.98 \\
7.16 \pm 1.99 \\
9.59 \pm 5.53 \\
0.424\end{array}$ \\
\hline
\end{tabular}

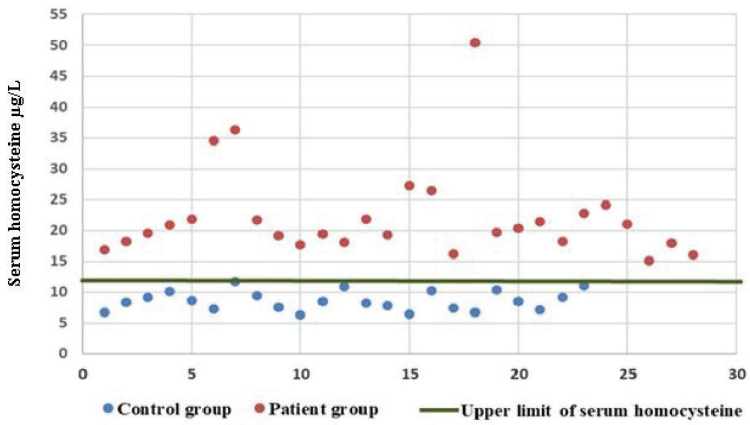

Figure 1: Serum homocysteine levels of the controls and patients

study groups. There was no significant difference between patients who had normal vitamin B12 levels and those who had low vitamin B12 in terms of crescent formation ( $p=0.641$ ). Serum folic acid level and thyroid function tests were within the normal range in all our patients. The frequency of $677 \mathrm{CC}, 677 \mathrm{CT}$, and 677TT genotypes was $32.2 \%, 61.2 \%$, and $6.4 \%$, respectively. The results for the 1298AA, 1298AC, and 1298CC genotypes were $19.3 \%, 77.4 \%$, and $3.2 \%$, respectively.

\section{DISCUSSION}

Crescent formation may occur at any time during the course of IgAN and HSPN. We previously observed crescents in two patients with both IgAN and hyperhomocysteinemia in our outpatient clinic. It has been reported that elevation of serum Hcy level has many harmful effects on the endothelium (23). Some of these effects are activation of coagulation and inhibition of fibrinolysis, increase of vascular tonus, and stimulation of oxidative stress (23). The effects of Hcy have also been demonstrated in glomeruli via some experimental studies $(11,13,14)$. Hence, we expected that serum Hcy levels might be higher in patients with crescents than in those without among children with IgAN and HSPN. On the contrary, Hcy levels were not different between patients with or without crescents in their glomeruli in our study group.

Interestingly, all of our patients had elevated serum Hcy levels. Therefore, we evaluated the well-known risk factors for hyperhomocysteinemia such as hypothyroidism, vitamin B12 and folic acid deficiency, and MTHFR gene polymorphisms (24). TT polymorphism of MTHFR C677T was found to be associated with decreased activity of MTHFR, which results in higher Hcy and lower folic acid levels. Also, it has been reported that the CC variant of MTHFR A1298C might be associated with lower enzyme activity, but results in the literature are less conclusive than for C677T (25-27). As possible causes of hyperhomocysteinemia, vitamin B12 deficiency was found in 12 patients (38.7\%) in our study group. Moreover, TT polymorphisms were detected 
in two patients and CC polymorphism in one patient. However, serum Hcy levels were also found elevated in the remaining 16 patients who did not have features that may predispose to hyperhomocysteinemia. We speculate that hyperhomocysteinemia may be related to IgAN itself because there was no other reason for hyperhomocysteinemia in these patients.

Endothelial cells have an important role in the maintenance of vascular structure integrity in glomeruli $(28,29)$. It has been considered that endothelial cells are related to the progression of IgAN. Kusano $T$ et al. evaluated the number of glomerular endothelial cells in patients with IgAN by examining the number of nuclei of CD34+ glomerular endothelial cells in renal biopsies (6). The authors demonstrated that the loss of CD34+ endothelial cells was associated with glomerular necrosis, segmental and global sclerosis in IgAN (6). Also, there were fewer $\mathrm{CD} 34+$ endothelial cells found in glomeruli with chronic lesions than in normal glomeruli in the biopsy samples (6). Moreover, hyperhomocysteinemia may aggravate endothelial damage and sclerotic modification in glomeruli $(11,13,30)$. According to Oxford Classifications, segmental glomerulosclerosis was related to the poor prognosis in IgAN (4). Hcy levels were significantly higher in patients with segmental sclerosis in their kidney biopsies in our study group, which suggests that hyperhomocysteinemia may be related to sclerosis and chronic changes in glomeruli and consequently poor prognosis in IgAN.

Proteinuria is another important factor that is known to impact the prognosis of patients with IgAN (31). Thus, the relationship between the serum Hcy levels and proteinuria was evaluated in our study. According to our results, there were no differences between the presence or absence of proteinuria and between the different levels of proteinuria in patients with IgAN in terms of serum Hcy levels. In our previous study, we evaluated whether there was Hcy elevation in idiopathic nephrotic syndrome in children. The serum Hcy levels were not higher in nephrotic children than in the control group (32). Kong et al. demonstrated that hyperhomocysteinemia was an independent risk factor of decreased eGFR in the elderly population, although there was no relationship between proteinuria and elevated serum Hcy levels in their study (33). On the contrary, Shuwei et al. reported that hyperhomocsyteinemia was associated with lower eGFR and also initial proteinuria in patients with IgAN (34). Although these studies had different results about the relationship between serum Hcy levels and proteinuria, they concluded that hyperhomocysteinemia was related to decreasing in eGFR and poor prognosis.

Our study had some limitations. One of these limitations was that our patients were not in the acute phase of the illness. The mean duration between kidney biopsy and blood sampling for the study was 35 months. We believe that further studies in larger groups of patients in the acute phase of the illness may reveal a relationship between these pathologic prognostic factors. The second limitation was our relatively small sample size.

In conclusion, we demonstrated that serum Hcy levels are elevated in patients with IgAN and HSPN. Our results suggest that elevated serum Hcy levels may be related to segmental glomerulosclerosis in these patient groups.

Ethics Committee Approval: This study was approved by the Clinical Research Ethical Committee of the Istanbul University, Istanbul Faculty of Medicine (Date: 27.05.2013, No: 640).

Informed Consent: Written consent was obtained from the participants.

Peer Review: Externally peer-reviewed.

Author Contributions: Conception/Design of Study- Z.Y.Y., A.Y., A.G., Y.Ö., S.E.; Data Acquisition- C.P., N.A., N.K.; Data Analysis/Interpretation- B.Y.A., Y.Ö., A.A.Ö., I.K.; Drafting Manuscript- C.P., N.A., N.K., A.K., B.Y.A., A.Ö., G.Ö.; Critical Revision of Manuscript- A.Y., Z.Y.Y., S.E., I.K., Y.Ö., A.G.; Final Approval and Accountability- C.P., Z.Y.Y., A.Y., A.G., N.K., M.K., A.Y., G.Ö., Y.Ö., I.K., A.A.Ö., B.Y.A., S.E.

Conflict of Interest: Authors declared no conflict of interest.

Financial Disclosure: Authors declared no financial support.

Etik Komite Onayı: Bu çalışma için etik komite onayı İstanbul Üniversitesi, İstanbul Tıp Fakültesi Klinik Araştırmalar Etik Kurulu'ndan alınmışıı (Tarih: 27.05.2013, No: 640).

Bilgilendirilmiş Onam: Katılımcılardan bilgilendirilmiş onam alınmışır.

Hakem Değerlendirmesi: Dış bağımsız.

Yazar Katkıları: Çalışma Konsepti/Tasarım- Z.Y.Y., A.Y., A.G., Y.Ö., S.E.; Veri Toplama- C.P., N.A., N.K.; Veri Analizi/Yorumlama- B.Y.A., Y.Ö., A.A.Ö., I.K.; Yazı Taslağı- C.P., N.A., N.K., A.K., B.Y.A., A.Ö., G.Ö.; İ̧̧eriğin Eleştirel İncelemesi- A.Y., Z.Y.Y., S.E., I.K., Y.Ö., A.G.; Son Onay ve Sorumluluk- C.P., Z.Y.Y., A.Y., A.G., N.K., M.K., A.Y., G.Ö., Y.Ö., I.K., A.A.Ö., B.Y.A., S.E.

Çıkar Çatışması: Yazarlar çıkar çatışması beyan etmemişlerdir.

Finansal Destek: Yazarlar finansal destek beyan etmemişlerdir.

\section{REFERENCES}

1. Nakanishi K, Yoshikawa N. Immunoglobulin A Nephropathy. In: Avner ED, Harmon WE, Niaudet P, Yoshikawa N, Emma F, Goldstein SL, editors. Pediatric Nephrology, 7th ed. Berlin Heidelberg: Springer-Verlag; 22016.pp983-1033.

2. Shima $Y$, Nakanishi $K$, Hama T, Mukaiyama $H$, Togawa $H$, Hashimura Y, et al. Validity of the Oxford classification of IgA nephropathy in children. Pediatr Nephrol 2012;27(5):783-92. [CrossRef] 
3. Coppo R, Davin JC. The difficulty in considering modifiable pathology risk factors in children with IgA nephropathy: crescents and timing of renal biopsy. Pediatr Nephrol 2014;30(2):189-92. [CrossRef]

4. Roberts IS, Cook HT, Troyanov S, Alpers CE, Amore A, Barratt J, et al. The Oxford classification of IgA nephropathy: pathology definitions, correlations, and reproducibility. Kidney Int 2009;76(5):546-56. [CrossRef]

5. Beck L, Bomback AS, Choi MJ, Holzman LB, Langford C, Mariani LH, et.al. KDOQI US Commentary on the 2012 KDIGO Clinical Practice Guideline for Glomerulonephritis. Am J Kidney Dis 2013;62(3):403-41. [CrossRef]

6. Kusano T, Takano H, Kang D, Nagahama K, Aoki M, Morita $M$, et al. Endothelial cell injury in acute and chronic glomerular lesions in patients with IgA nephropathy. Human Pathology 2015;49:135-44. [CrossRef]

7. Rodgers GM, Conn MT. Homocysteine, an atherogenic stimulus, reduces protein $\mathrm{C}$ activation by arterial and venous endothelial cells. Blood 1990;75(4):895-901. [CrossRef]

8. Rodgers GM, Kane WH. Activation of endogenous factor $\checkmark$ by homocysteine-induced vascular endothelial cell activator. J Clin Invest 1986;77(6):1909-16. [CrossRef]

9. Tsai JC, Perrella MA, Yoshizumi M, Hsieh CM, Haber E, Schlegel R, et al. Promotion of vascular smooth muscle cell growth by homocysteine: a link to atherosclerosis. Proc Natl Acad Sci 1994;91(14):6369-73. [CrossRef]

10. Farid FA, Faheem MS, Heshmat NM, Shaheen KY, Saad SS. Study of the homocysteine status in children with chronic renal failure. Am J Nephrol 2004;24(3):289-95. [CrossRef]

11. Kumagai $H$, Katoh $S$, Hirosawa K, Kimura M, Hishida A, Ikegaya N. Renal tubulointerstitial injury in weanling rats with hyperhomocysteinemia. Kidney Int 2002;62(4):1219-28. [CrossRef]

12. Kanani PM, Sinkey CA, Browning RL, Allaman M, Knapp HR, Haynes WG. Role of oxidant stress in endothelial dysfunction produced by experimental hyperhomocyst(e)inemia in humans. Circulation 1999;100(11):1161-8. [CrossRef]

13. LiN, Chen YF, Zou AP. Implications of hyperhomocysteinemia in glomerular sclerosis in hypertension. Hypertension 2002;39(2 Pt 2):443-8. [CrossRef]

14. Hwang SY, Woo CW, Au-Yeung KK, Siow YL, Zhu TY, O K. Homocysteine stimulates monocyte chemoattractant protein-1 expression in the kidney via nuclear factor-kappaB activation. Am J Physiol Renal Physiol 2007;294(1):F236-44. [CrossRef]

15. Dillon MJ, Ozen S. A new international classification of childhood vasculitis. Pediatr Nephrol 2006;21(9):1219-22. [CrossRef]

16. Roberts IS. Pathology of IgA nephropathy. Nat Rev Nephrol 2014;10(8):445-54. [CrossRef]

17. Flynn JT, Kaelber DC, Baker-Smith CM, Blowey D, Carroll AE, Daniels SR, et al. Clinical practice guideline for screening and management of high blood pressure in children and adolescents. Pediatrics 2017;140(3): e20171904. [CrossRef]

18. Schwartz GJ, Munoz A, Schneider MF, Mak RH, Kaskel F, Warady BA, et al. New equations to estimate GFR in children with CKD. J Am Soc Nephrol 2009;20(3):629-37.[CrossRef]

19. Yap HK, Lau PY. Hematuria and Proteinuria. In: Geary FD, Schaefer F, editors. Comprehensive Pediatric Nephrology, $1^{\text {st }}$ ed. Philadelphia: Mosby Elseiver; 2008.pp179-93. [CrossRef]
20. Nicholson JF, Pesce MA. Reference ranges for laboratory tests and procedures. In: Behrman RE, Kliegman RM, Jenson HB, editors. Nelson Textbook of Pediatrics, 17th ed. Philadelphia: Saunders; 2004.pp2396-427.

21. Carmel R. Biomarkers of cobalamin (vitamin B-12) status in the epidemiologic setting: a critical overview of context, applications, and performance characteristics of cobalamin, methylmalonic acid, and holotranscobalamin II. Am J Clin Nutr 2011;94(1):348-58. [CrossRef]

22. Glader B. Anemias of Inadequate Production. In: Kliegman RM, Behrman HR, Jenson HB, Stanton BF, editors. Nelson Textbook of Pediatrics, $18^{\text {th }}$ ed. Philadelphia: Saunders; 2007.pp2006-18.

23. Stanger $O$, Weger $M$, Renner $W$, Konetschny R. Vascular dysfunction in hyperhomocyst(e)inemia. Implications for atherothrombotic disease. Clin Chem Lab Med 2001;39(8):725-33. [CrossRef]

24. Refsum H, Ueland PM, Nygard O, Vollset SE. Homocysteine and cardiovascular disease. Annu Rev Med 1998;49:31-62. [CrossRef]

25. Weisberg I, Tran P, Christensen B, Sibani S, Rozen R. A second genetic polymorphism in methylenetetrahydrofolate reductase (MTHFR) associated with decreased enzyme activity. Mol Genet Metab 1998;64(3):169-72. [CrossRef]

26. Friedman $G$, Goldschmidt $N$, Friedlander $Y$, Ben-Yehuda A, Selhub J, Babaey S, et al. A common mutation A1298C in human methylenetetrahydrofolate reductase gene: association with plasma total homocysteine and folate concentrations. J Nutr 1999;129(9):1656-61. [CrossRef]

27. Lievers KJ, Boers GH, Verhoef $P$, den Heijer M, Kluijtmans $L A$, van der Put NM, et al. A second common variant in the methylenetetrahydrofolate reductase (MTHFR) gene and its relationship to MTHFR enzyme activity, homocysteine, and cardiovascular disease risk. J Mol Med (Berl) 2001;79(9):5228. [CrossRef]

28. Carmeliet P, Collen D. Vascular development and disorders: molecular analysis and pathogenic insights. Kidney Int 1998;53(6):1519-49. [CrossRef]

29. Endemann DH, Schiffrin EL. Endothelial dysfunction. J Am Soc Nephrol 2004;15(8):1983-92. [CrossRef]

30. McCully KS. Vascular pathology of homocysteinemia; implications for the pathogenesis of arteriosclerosis. Am J Pathol 1969;56:111-28.

31. Coppo R, D'Amico G. Factors predicting progression of IgA nephropathies. J Nephrol 2005;18(5):503-12.

32. Aksu B, Emre S, Yılmaz A, Yürük ZN, Demirel ÜDM, Erol $O B$, et al. The relationship between serum asymmetric dimethylarginine levels and cardiovascular risk factors in children with nephrotic syndrome. Med Bull Haseki 2019;57:122-8. [CrossRef]

33. Kong X, Ma X, Zhang C, Su X, Xu D. Hyperhomocysteinemia increases the risk of chronic kidney disease in a Chinese middle-aged and elderly population-based cohort. Int Urol Nephrol 2017;49(4):661-7. [CrossRef]

34. Duan S, Liu S, Sun X, Zheng Y, Liu L, Yao F, et al. Potential association of hyperhomocysteinemia with the progression of IgA nephropathy: a retrospective study. Chin Med J 2014;127(10):1849-52. 